\title{
SERUM 25-HYDROXYVITAMIN D, PARATHYROID HORMONE, CALCIUM INTAKE, AND BONE MINERAL DENSITY IN SPANISH ADULTS
}

\begin{abstract}
José M. Olmos, $\mathrm{MD}, \mathrm{PhD}^{1}$, José L. Hernández, $\mathrm{MD}, \mathrm{PhD}^{1}$, Pilar García-Velasco, $\mathrm{MD}, \mathrm{PhD}^{2}$, Josefina Martínez, MD, $\mathrm{PhD}^{1}$, Javier Llorca, $\mathrm{MD}, \mathrm{PhD}^{3}$, Jesús González-Macías, $\mathrm{MD}, \mathrm{PhD}^{1}$.

${ }^{1}$ Bone Metabolic Unit. Department of Internal Medicine, Hospital Universitario Marqués de Valdecilla. IDIVAL. University of Cantabria. Red Temática de Investigación Cooperativa en Envejecimiento y Fragilidad (RETICEF). Santander, Spain. ${ }^{2}$ Centro de Salud Camargo, Santander, Spain. ${ }^{3}$ Epidemiology Unit, Medical School, University of Cantabria, Centro de Investigación Biomédica en Red Epidemiología y Salud Pública (CIBERESP), Santander, Spain.
\end{abstract}

Abbreviated title: 25OHD, PTH, calcium intake and BMD in Spanish adults

Key words: $25(\mathrm{OH}) \mathrm{D}$, dairy calcium intake, bone mineral density, parathyroid hormone.

Word count: 3562

Number of figures and tables: 6

Correspondence to:

José M. Olmos

Bone Metabolic Unit. Department of Internal Medicine

Hospital Universitario Marqués de Valdecilla

Avda. Valdecilla s/n. 39008-Santander, Spain

Phone:+34942202513

Fax: +34942201695

e-mail: miromj@humv.es

Supported by grants from the "Instituto de Salud Carlos III-FIS" (PI11/01092), and Red Temática de Investigación Cooperativa en Envejecimiento y Fragilidad (RETICEF; RD06/0013/1007). "Instituto de Salud Carlos III". Spain.

Conflicts of interest: José M. Olmos, José L. Hernández, Pilar García-Velasco, Josefina Martínez, Javier Llorca, and Jesús González-Macías declare that they have no conflict of interest. 


\begin{abstract}
Purpose: To assess 25-hydroxyvitamin D -25(OH)D- status in Spanish adult subjects, and to analyze its relationships with serum PTH levels, calcium intake and bone mineral density (BMD).
\end{abstract}

Methods: A total of 1811 individuals (1154 postmenopausal women and 657 men) aged 44-93 years participated in the study. Serum $25(\mathrm{OH}) \mathrm{D}$, intact parathyroid hormone (PTH), aminoterminal propeptide of type I collagen (P1NP), and C-terminal telopeptide of type I collagen ( $\beta$-CTX) levels, were measured by electrochemiluminescence. BMD was determined by dual X-ray absorptiometry (DXA) at lumbar spine, femoral neck and total hip.

Results: Serum 25(OH)D levels were below 10, 20 and $30 \mathrm{ng} / \mathrm{ml}$ in 5\%, 40\%, and 83\% of participants, respectively. There was a significant seasonal difference in mean serum $25(\mathrm{OH}) \mathrm{D}$, with higher levels in summer-autumn. In multivariate analysis, 25(OH)D levels were negatively correlated with age, serum PTH and creatinine, body mass index, smoking, alcohol intake, and number of chronic diseases, but positively with dairy calcium intake. The magnitude of the difference in serum PTH according to $25(\mathrm{OH}) \mathrm{D}$ quartiles was not influenced by calcium intake. A threshold of serum $25(\mathrm{OH}) \mathrm{D}$ around $30 \mathrm{ng} / \mathrm{ml}$ was observed for serum PTH and hip BMD.

Conclusions: Vitamin D insufficiency is very common among Spanish communitydwelling adult subjects. A threshold of serum 25(OH)D around $30 \mathrm{ng} / \mathrm{ml}$ would be necessary for the prevention of secondary hyperparathyroidism and hip bone loss in our population, regardless of the dairy calcium ingestion. Programs to improve vitamin D status may be required in our country. 


\title{
Mini Abstract
}

\begin{abstract}
Vitamin D insufficiency was very common among Spanish community-dwelling adult subjects. A threshold of serum 25(OH)D around $30 \mathrm{ng} / \mathrm{ml}$ would be necessary for the prevention of secondary hyperparathyroidism and hip bone loss in our population, regardless of the dairy calcium ingestion.
\end{abstract}




\section{Introduction}

Vitamin D deficiency is extremely common among elderly subjects. It causes secondary hyperparathyroidism, high bone turnover, bone loss, mineralization defects, and fractures, and it has also been associated to a number of other conditions, such as impaired muscle function and some tumours (1). Since vitamin $\mathrm{D}_{3}$ is synthesized in the skin under the influence of UV irradiation, vitamin D status depends on latitude, so people living in sunny countries are at lower risk. However, previous studies $(2,3)$ and more recent surveys (4-6) among people from different European countries, have shown that the greatest incidence of hypovitaminosis D occurs in the Mediterranean area.

An inverse association between serum 25-hydroxyvitamin D -25(OH)D- and serum parathyroid hormone $(\mathrm{PTH})$ is well established, up to a certain level of $25(\mathrm{OH}) \mathrm{D}$, in which little further decrease in serum PTH is observed. The serum level of $25(\mathrm{OH}) \mathrm{D}$ at which PTH becomes constant has been used to identify the lower desirable concentration of serum 25(OH)D. Estimates of threshold levels of $25(\mathrm{OH}) \mathrm{D}$ varies greatly from 8 to $44 \mathrm{ng} / \mathrm{ml}(6,7,8)$. This wide range may be due, in part, to different methods for measuring both serum PTH and 25(OH)D levels $(6,9)$, and possibly also due to different characteristics of the studied populations (10). Previous studies suggest that the relationship between PTH and $25(\mathrm{OH}) \mathrm{D}$ is modulated by both age and calcium intake (11,12). However, other environmental (latitude, season, clouds) and personal factors (skin type, age, clothing, renal function, number of chronic diseases, etc.) could also be taken into account $(6,10,12,13)$.

Therefore, the aim of this study was: i) to describe the $25(\mathrm{OH}) \mathrm{D}$ status according to season, in Spanish postmenopausal women and men $\geq 50$ years, and ii) to analyze its relationships with age, serum PTH, calcium intake, and BMD. 


\section{Subjects and methods}

\section{Study design and participants}

The study population consists of those men and women included in the Camargo Cohort Study. Full details of this cohort study have been previously reported $(14,15)$. The cohort was set up with the postmenopausal women and men aged 50 years and older attending a primary care center in Northern Spain for medical reasons or for their regular health examination, whichever happened first. All participants were white, as are more than $95 \%$ of people in our region (Cantabria) $\left(43^{\circ} \mathrm{N}\right.$ latitude). The study was approved by the local Ethics Committee, and all subjects gave written informed consent.

At the baseline visit, subjects were interviewed by investigators and all participants provided data regarding the risk factors of osteoporosis and fractures using a structured questionnaire which included age, race, weight, height, body mass index (BMI), personal antecedents of fractures in adulthood ( $>40$ years), history of osteoporotic fractures among first-degree relatives, tobacco use, consumption of dairy products, alcohol use (g/day), physical exercise, the number of falls in the previous year, the presence of chronic diseases (cardiovascular disease, chronic obstructive pulmonary disease, stroke, diabetes mellitus, and joint disorders including rheumatoid arthritis), and present or past consumption of medications. BMI was defined as weight (kg) divided by squared height $\left(\mathrm{m}^{2}\right)$. Dairy calcium consumption was assessed by a food frequency questionnaire (16). Level of education was assessed by asking for the highest educational level completed, ranging from none to university. Tobacco smoking was assessed as current smoker, or never smoker. Alcohol consumption was defined as $>20$ g of alcohol per day. Habitual physical activity was classified as high (moving, walking and working energically and participating in vigorous exercise), moderate (walks 
reasonable distances, does light housework shopping or equivalent, normal activities of day-to-day living but no appreciable exercise), and sedentary (little walking outside home, or sits in a chair or lies in bed most of the time). In order to evaluate the seasonal variation of serum $25(\mathrm{OH}) \mathrm{D}$, the period July-November represented summer-autumn, and the period December-April, winter-spring. The presence of chronic diseases (cardiovascular disease, stroke, chronic obstructive pulmonary disease, diabetes mellitus, chronic liver diseases, malignant neoplasms, and rheumatoid arthritis) was assessed through a detailed questionnaire.

Participants whose baseline assessment revealed the presence of diseases or treatments known to affect bone metabolism, such as osteoporosis, primary hyperparathyroidism, hyperthyroidism, serum creatinine $>1.7 \mathrm{mg} / \mathrm{dl}(151 \mu \mathrm{mol} / \mathrm{L})$, or use of bisphosphonates, oestrogen, raloxifene, strontium ranelate, teriparatide, Lthyroxin, anticonvulsants or glucocorticoids in the previous 1 year, were excluded from the study. Participants on calcium and/or vitamin D supplements were also excluded.

\section{Biochemical tests}

For each participant, fasting blood samples were collected between 09:00 and 10:30 h. Serum was divided into $0.5-\mathrm{ml}$ aliquots and stored at $-40^{\circ} \mathrm{C}$. Serum total calcium (TCa), phosphate, creatinine, albumin, and total alkaline phosphatase were measured by standard automated methods in an ADVIA 2400 Chemistry System autoanalyser (Siemens, Germany). TCa measurements were corrected for albumin concentration (cCa) following a previously published formula (17). Serum concentrations of $25(\mathrm{OH}) \mathrm{D}$, intact PTH, P1NP, and $\beta$-CTX were determined by a fully automated Roche electrochemiluminescence system (Elecsys 2010, Roche Diagnostics, $\mathrm{GmbH}$, Mannheim, Germany). The detection limit of serum $25 \mathrm{OHD}$ was $4 \mathrm{ng} / \mathrm{ml}$, its intraassay coefficient of variation (CV) 5\%, and its interassay CV 7.5\%. Regarding 
intact PTH, the detection limit was $6 \mathrm{pg} / \mathrm{ml}$, with a normal range of 15-65 pg/ml. Intraassay and interassay CV were $3.4 \%$ and $5.9 \%$, respectively. The P1NP limit of detection was $5 \mathrm{ng} / \mathrm{ml}$ (reference range between $15-78 \mathrm{ng} / \mathrm{ml}$ ), and its intraassay and interassay CV were $3.9 \%$ and $4.1 \%$, respectively [14,17]. Intraassay and interassay CV for $\beta$-CTX were $4.2 \%$ and $4.7 \%$, also respectively, and the detection limit was 0.01 $\mathrm{ng} / \mathrm{ml}(14,15)$.

\section{DXA measurements}

BMD was measured by DXA (Hologic QDR 4500, Bedford, MA, USA) at the lumbar spine (LS), femoral neck (FN), and total hip (TH) in all the 1811 subjects who finally entered the study (see below). In vivo precision was $0.4-1.5 \%$ at the different measurement sites. Results were expressed as grams per square centimetre. Quality control was performed according to the usual standards $(18,19)$.

\section{Statistical analysis}

Baseline characteristics of the population were calculated for the total sample and for men and women separately. All continuous variables were tested for normality. Variables non-normally distributed underwent logarithmic transformation before statistical analyses. Results were expressed as mean $\pm \mathrm{SD}$, median [interquartile range] or percentages, as appropriate. Student's $t$ test or Mann-Whitney U-test was used to determine the differences between groups for continuous variables, and $\chi^{2}$-test for categorical variables. Stepwise multiple linear regression analysis was conducted to identify independent predictors of serum 25(OH)D levels. Participants were divided according to age groups $(<60 ; 60-75 ;>75$ years $)$, serum $25(\mathrm{OH}) \mathrm{D}$ quartiles $(<17 ; 17$ $22 ; 22-28 ;>28 \mathrm{ng} / \mathrm{ml})$ and dairy calcium intake tertiles (<450; 450-700; >700 mg/day). Analysis of variance was used to compare the outcome variables between groups, 
applying the Bonferroni method for multiple comparisons. A multivariable general lineal model, adjusted for potential confounders (age, sex, BMI, level of education, exercise, alcohol use, smoking, number of chronic diseases, serum creatinine, and season of vitamin D determination), was used to compare mean values of the main variables across quartiles of serum 25(OH)D. Finally, locally weighted regression smoothing (LOESS) plots, also adjusted for the same confounders, were performed to analyze the relationship between serum $25(\mathrm{OH}) \mathrm{D}$ levels and various outcome measures. A p value $<0.05$ was considered statistically significant in all the calculations.

\section{RESULTS}

A total of 2308 individuals (1573 postmenopausal women with no menses for at least 12 months, and 735 men $\geq 50$ years) were recruited. Of them, 497 were excluded because their baseline study revealed the presence of diseases or treatments known to affect bone metabolism, or even treatments addressed to bone metabolic diseases, including osteoporosis, as well as calcium and/or vitamin D supplements. The remaining 1811 subjects (1154 women and 657 men) were entered into the study. Epidemiological characteristics, as well as biochemical, and BMD results of the study population are showed in Table 1 . Serum $25(\mathrm{OH}) \mathrm{D}$ was significantly higher in men than in women, whereas mean PTH levels did not differ. Serum P1NP and $\beta$-CTX concentrations were higher in women than in men. Conversely, BMD was significantly higher in men than in women. There was a non-significant negative correlation between serum 25(OH)D and P1NP $(r=-0.005 ; \mathrm{p}=0.84)$ or $\beta-\mathrm{CTX}(\mathrm{r}=-0.01 ; \mathrm{p}=0.68)$.

The distribution of participants according to various serum $25(\mathrm{OH}) \mathrm{D}$ cut-offs was as follows: $5 \%$ of subjects had serum levels of $25(\mathrm{OH}) \mathrm{D}<10 \mathrm{ng} / \mathrm{ml}, 40 \%<20$ $\mathrm{ng} / \mathrm{ml}, 83 \%<30 \mathrm{ng} / \mathrm{ml}$, and $17 \%>30 \mathrm{ng} / \mathrm{ml}$. There was a significant seasonal difference 
in mean serum $25(\mathrm{OH}) \mathrm{D}$, with a higher level in summer-autumn $(26.2 \pm 8.3 \mathrm{ng} / \mathrm{ml})$ than in winter-spring $(20.4 \pm 7.6 \mathrm{ng} / \mathrm{ml} ; \mathrm{p}<0.0001)$.

Sex and BMI adjusted serum 25(OH)D levels were negatively correlated with age $(\mathrm{r}=-0.21 ; \mathrm{p}<0.0001)$. As it can be seen in Table 2, mean serum 25(OH)D concentration was lower at older ages. Conversely, PTH levels were higher in older people, and a positive correlation with age was observed $(\mathrm{r}=0.30 ; \mathrm{p}<0.0001)$. However, unlike 25(OH)D and PTH, dairy calcium intake did not significantly vary among different age groups.

Table 3 shows the mean values of PTH, bone markers, BMD, and calcium intake for different 25(OH)D quartile groups, adjusted for age, sex, BMI, level of education, exercise, alcohol use, smoking, number of chronic diseases, serum creatinine levels, and season of vitamin D determination. As it can be seen, mean serum PTH decreased in higher quartiles, and dairy calcium intake increased. No differences in both bone turnover markers were seen between the lowest and highest quartiles. Femoral neck and hip BMD values were higher in the highest serum $25(\mathrm{OH}) \mathrm{D}$ quartile than in the lowest.

Results of the stepwise multiple linear regression analysis is showed in the Table 4. Variables included in the model explained $21 \%$ of the variance in serum $25(\mathrm{OH}) \mathrm{D}$ levels in adult men and women.

The relationship between $25(\mathrm{OH}) \mathrm{D}$ and some bone parameters is presented in the Figure 1. LOESS plots with $95 \%$ confidence intervals, adjusted for confounders show the mean values of serum PTH, BMD, and dairy calcium intake for each value of serum 25(OH)D. As it has been mentioned above, in the overall population, serum PTH was inversely correlated with $25(\mathrm{OH}) \mathrm{D}$ (unadjusted $\mathrm{r}=-0.28$; $\mathrm{p}<0.0001$ ). However, at serum $25(\mathrm{OH}) \mathrm{D}$ levels $>30 \mathrm{ng} / \mathrm{ml}$, this relationship became statistically non-significant, and a plateau in serum PTH levels was observed (Figure 1A). For the relationship between serum 25(OH)D and femoral neck and total hip BMD, a threshold appeared to 
exist around the serum 25(OH)D level of $30 \mathrm{ng} / \mathrm{ml}$ (Figures 1B, and 1C). Concerning dairy calcium intake, the threshold seems to be apparent around $25(\mathrm{OH}) \mathrm{D}$ levels of 35 $\mathrm{ng} / \mathrm{ml}$ (Figure $1 \mathrm{D})$.

Finally, the magnitude of the difference in serum PTH levels according to 25(OH)D quartiles, was similar in patients with different calcium intake (Figure 2). The lowest serum PTH levels were observed in the group with a serum 25(OH)D higher than $28 \mathrm{ng} / \mathrm{ml}$, whereas the highest value was found in the group with serum $25(\mathrm{OH}) \mathrm{D}$ lower than $17 \mathrm{ng} / \mathrm{ml}$. However, no statistical differences were found in adjusted PTH values according to serum $25(\mathrm{OH}) \mathrm{D}$ quartiles among different calcium intake subgroups.

\section{Discussion}

Results of this survey show that mean serum $25(\mathrm{OH}) \mathrm{D}$ concentration in community-dwelling postmenopausal women and adult men of our region is around 23 $\mathrm{ng} / \mathrm{ml}$. This finding is quite similar to that reported from the UK National Diet and Nutrition Survey (2000-2001) of British adolescents and adults (20) and from people of our antipodes (New Zealand) (21), but lower than in the USA and Northern European population $(3-6,22)$. We also found a low prevalence $(5 \%)$ of severe vitamin D deficiency (serum values $<10 \mathrm{ng} / \mathrm{ml}$ ) but a high prevalence $(40 \%)$ of vitamin $\mathrm{D}$ insufficiency (values $<20 \mathrm{ng} / \mathrm{ml}$ ) in postmenopausal women and adult men of our region. Moreover, less than $20 \%$ of our mostly independent-living middle-aged and older subjects had values higher than $30 \mathrm{ng} / \mathrm{ml}$, that are considered by most authors as the minimum desirable serum $25(\mathrm{OH}) \mathrm{D}$ concentration $(23,24)$. Our findings are in accordance with those reported from other European Mediterranean countries (2-6), and also with results obtained by other authors in Spain (25-33). Thus, Gomez Alonso et al. (25) showed a high prevalence of vitamin D deficiency (27\%) and insufficiency (40\%) 
among 326 subjects of similar age (68 99 years), participating in the European Vertebral Osteoporosis Study (EVOS). González-Molero, et al (26) analyzed 1262 subjects aged 20-83 years, and observed a $34 \%$ of vitamin D insufficiency $(<20 \mathrm{ng} / \mathrm{ml})$ with a mean $25 \mathrm{OHD}$ values of $22.5 \mathrm{ng} / \mathrm{ml}$. Furthermore, the prevalence of vitamin D deficiency and insufficiency was higher in the elderly, specially in institutionalized subjects $(27,28)$, but it was also relevant in younger healthy populations (29), in postmenopausal women (30,31), and even in children (32). The relatively low proportion of vitamin D deficiency in our study would be, at least in part, due to the different methods for measuring $25(\mathrm{OH}) \mathrm{D}$ and to the characteristics of our population (mostly independentliving middle aged subjects) $(6,9)$. On the other hand, consumption of fortified foods has increased during the last years in our country (33), and accordingly with our results, recent data suggest that the prior situation of a high prevalence of vitamin D deficiency has improved in Spain (34).

We found a significant seasonal difference in serum $25(\mathrm{OH}) \mathrm{D}$ levels, with the lowest concentrations occurring in the winter-spring and the highest during the summerautumn periods $(20.4 \pm 7.6 \mathrm{ng} / \mathrm{ml}$ vs. $26.2 \pm 8.3 \mathrm{ng} / \mathrm{ml} ; \mathrm{p}<0.0001)$. Seasonal variations in serum 25OHD concentrations have been demonstrated for different populations at a range of latitudes $(2,3,6)$. The present study was carried out in Camargo, a city in the North coast of Spain located at latitude $43^{\circ} \mathrm{N}$, with a temperate climate (average temperature, $\left.14^{\circ} \mathrm{C}\right), 1638$ hours of sunlight per year, $1249 \mathrm{~mm}$. precipitation per year, and were it rarely snows or freezes. Vitamin D levels were $30 \%$ higher in summerautumn than in the winter-spring period, a situation similar to those described previously in Spanish postmenopausal women $(4,25,26)$, that reflects the differences in solar exposition. In fact, in our study the prevalence of vitamin D insufficiency $(<20$ $\mathrm{ng} / \mathrm{ml}$ ) in the winter-spring period was $53 \%$, supporting the limited capacity of vitamin 
D skin synthesis in winter in latitudes above $40^{\circ} \mathrm{N}(35,36)$. Nevertheless, summer/winter difference was much lower than differences observed several years ago in children from our region (32). This may reflect the higher sunshine exposition and the better response to cutaneous synthesis in infancy $(1,2,37)$. On the other hand, as we have previously stated, higher consumption of fortified foods among Spanish adults has been described in recent years (33). The association between vitamin D status and dairy calcium intake that we observed in our population would be in accordance with this idea. Finally, the higher use of sunscreen during summer, especially among women, would also contribute to explain these findings $(38,39)$.

In the present study, serum $25(\mathrm{OH}) \mathrm{D}$ concentrations were higher in men than in women and decreased with age. Our results are again in agreement with those reported by other authors $(3,5,6,12)$. Higher sunlight exposure and lower BMI in men, could explain at least in part, gender differences $(1,6)$. Reasons for the decline in vitamin D status with age are well known and include impaired vitamin D absorption in the intestine and a decline in the ability of the skin to produce vitamin D3 $(1,2,12,37)$.

We found a significant association between low serum 25OHD levels and increased serum PTH and creatinine values, smoking habit, alcohol consumption, BMI, and increase in number of chronic diseases, as well as with low dairy calcium intake. It is well known that an insufficiency of vitamin D is generally associated with an increase in serum PTH $(1,4,7)$, although other factors must be entertained. Thus, vitamin D status is also associated with renal function, and glomerular filtration rate is a major determinant of the PTH response to decreasing serum levels of 25(OH)D (40). Smokers and obese people have previously been identified as having lower levels of serum $25(\mathrm{OH}) \mathrm{D}(41)$, and alcohol intake and number of chronic diseases have also been related with low levels of $25(\mathrm{OH}) \mathrm{D}(4,6,10)$. Finally, in our study, dairy calcium intake was positively associated with serum $25(\mathrm{OH}) \mathrm{D}$ levels. This observation indicates that in 
a large proportion of our subjects, hypovitaminosis D would be associated with low calcium intake, a situation also compatible with a relevant nutritional contribution to vitamin D status in our region. In our study, the magnitude of the difference in serum PTH according to $25(\mathrm{OH}) \mathrm{D}$ quartiles was similar among different calcium intake groups (Fig. 2). Steingrimsdottir et al. (11), have shown, in healthy Icelandic adults, that a serum $25(\mathrm{OH}) \mathrm{D}$ level $>10 \mathrm{ng} / \mathrm{ml}$ would ensure adequate values of serum PTH even when the calcium intake level was low $(<800 \mathrm{mg} / \mathrm{d})$, while high calcium intake $(>1200$ $\mathrm{mg} / \mathrm{d}$ ) was not sufficient to maintain ideal serum PTH levels, as long as vitamin D status is insufficient. Adami et al. (12), in a study conducted in Italian postmenopausal women with lower calcium intake and higher prevalence of vitamin D insufficiency than the Icelandic people, found that the effect of calcium intake on serum PTH was stronger and visible for all $25(\mathrm{OH}) \mathrm{D}$ levels. Calcium intake was relatively low in our sample, reflecting the common dietary pattern in Spain (16). However, our results are more in accordance with those reported by Steingrimsdottir et al. (11) than with those by Adami et al. (12), suggesting that vitamin D sufficiency might ensure adequate PTH values even when dairy calcium intake is lesser than $450 \mathrm{mg} / \mathrm{d}$.

We did not find a significant relationship between bone remodelling markers, both P1NP and $\beta$-CTX, and serum $25(\mathrm{OH}) \mathrm{D}$ values. This is in disagreement with some, but not all, studies $(4,13,35,42)$. Thus, Kuchuk et al. (13) found higher serum osteocalcin and urinary deoxypyridinoline (UDPYD) levels in older persons with lower serum $25(\mathrm{OH}) \mathrm{D}$, compared with those with higher values. The same group also showed that serum osteocalcin and $\beta$-CTX levels were significantly lower in osteoporotic postmenopausal women with the highest values of 25(OH)D (4). However, McDonald et al. (35), observed a significant association between vitamin D status and higher UDPYD levels, but not with serum P1NP, in postmenopausal British women. Finally, Nimitphong et al. (42), did not found any correlation between 25(OH)D levels and 
serum bone markers (P1NP and $\beta$-CTX) measured by electrochemiluminiscence, in 1734 healthy Thai individuals. Therefore, we could speculate that the characteristics of the population, the type of bone marker analyzed, and perhaps, some methodological aspects, would explain these differences.

There are important discrepancies to define vitamin D inadequacy. Cut-offs indicating vitamin D insufficiency have been based on the relationship between $25(\mathrm{OH}) \mathrm{D}$ and maximizing calcium absorption, minimizing the loss of BMD, and reducing the risk of falls and fractures $(1,6,10)$. However, the majority of evidence is based on the concentration of $25(\mathrm{OH}) \mathrm{D}$ above which there is no further suppression of PTH. This approach has led to a wide range of threshold levels $(4,7,8)$. The variability of these estimates may be related to the varied ethnicity and ages of the populations studied, varied calcium intake, presence of illness that may affect PTH concentrations, renal insufficiency, lack of standardization of assays for $25(\mathrm{OH}) \mathrm{D}$, and the mathematical analyses used (4,8-13). Recently, the Institutes of Medicine (IOM) revised the recommended $25(\mathrm{OH}) \mathrm{D}$ serum levels, setting it at or above $20 \mathrm{ng} / \mathrm{ml}$ to sustain bone density, calcium absorption, and to minimize the risk of osteomalacia (43). However, the International Osteoporosis Foundation (IOF) defines $30 \mathrm{ng} / \mathrm{ml}$ as the threshold of $25(\mathrm{OH}) \mathrm{D}$ to reduce falls and fractures (23). Such recommendation has also been endorsed by the US Endocrine Society [24]. In our study, adjusted LOESS plots showed that serum PTH reach a plateau when serum $25(\mathrm{OH}) \mathrm{D}$ was $>30 \mathrm{ng} / \mathrm{ml}$. Furthermore, BMD at femoral neck and total hip increased up to serum $25(\mathrm{OH}) \mathrm{D}$ levels of $30 \mathrm{ng} / \mathrm{ml}$. These results suggest that, in our population, a threshold of serum $25(\mathrm{OH}) \mathrm{D}$ level of 30 $\mathrm{ng} / \mathrm{ml}$ would be necessary for the prevention of secondary hyperparathyroidism ad hip bone loss. This would be more in accordance with IOF and US Endocrine Society estimation of optimal serum $25(\mathrm{OH}) \mathrm{D}$ concentrations $(23,24)$. Our findings would also be in line with a previous study conducted by Aloia et al. (44) in calcium-sufficient 
middle-aged African American women, in which a serum concentration higher than 20 ng/ml was necessary to prevent a rise in PTH concentrations. Kuchuk et al. (13), in older persons of the LASA cohort, established the optimal serum $25(\mathrm{OH}) \mathrm{D}$ in at least 20 $\mathrm{ng} / \mathrm{ml}$, a situation that was also observed by these authors in osteoporotic postmenopausal women from different countries (4). Nevertheless, these authors (13) following a similar methodology (LOESS plots) observed a continuous decline in serum PTH with increasing serum $25(\mathrm{OH}) \mathrm{D}$ and no plateau, a situation that has also been described in some other $(44)$, but not all $(26,45)$ studies, using a different methodology.

Accepting the cut-off value of $30 \mathrm{ng} / \mathrm{ml}$, would implicate that more than $80 \%$ of our community-dwelling postmenopausal women and adult men would have vitamin D insufficiency. Therefore, instead of the increment during recent years in our country of available commercial dairy products supplemented with calcium and/or vitamin $\mathrm{D}$, programs to improve vitamin D status of Spanish adult population, such as fortification and/or supplementation, may be required.

Our study has several limitations. As an observational study, it is therefore subject to some possible bias due to confounding factors. However, adjustment for many potential confounding factors such as age, sex, BMI, level of education, exercise, alcohol use, smoking, number of chronic diseases, serum creatinine levels, and season of vitamin D determination, has been carried out. The study population includes ambulatory community-dwelling postmenopausal women and adult men recruited from a Primary Care Centre of our region. In our health care system, people of a certain age are asked to visit their family doctors regularly, at least once a year; therefore, after this period of time, postmenopausal women and men older than 50 are expected to have attended the clinic. Hence our cohort may be considered representative of the general community-welling population. However, because it does not include persons compelled to live permanently at home or in a nursing home, our population might be at 
lower risk of hypovitaminosis D than the whole population of our region. An additional potential limitation is the fact that serum magnesium was not measured. Among the strengths we want to emphasize, it is worth mentioning that the participants were wellcharacterized, and all men and postmenopausal women were carefully studied from the mineral and bone metabolism point of view, and excluded if any disease or treatment known to affect this were present. Additionally, participants on calcium and/or vitamin D supplements were also excluded. Finally, all samples were obtained at the same time of the day and in a fasting state. Thus factors to minimize biological variability were controlled.

In conclusion, vitamin $\mathrm{D}$ insufficiency is very common among Spanish ambulatory community-dwelling adult people. Serum concentrations of $25(\mathrm{OH}) \mathrm{D}$ were lowest in the winter and highest in the summer, and decreased with age. Vitamin D status was also related with serum creatinine levels, smoking and alcohol use, increase in number of chronic diseases, low BMI and dairy calcium intake. A threshold of serum $25(\mathrm{OH}) \mathrm{D}$ around $30 \mathrm{ng} / \mathrm{ml}$ would be necessary for the prevention of secondary hyperparathyroidism and hip bone loss in our population regardless of the dairy calcium ingestion. Therefore, programs to improve vitamin D status of Spanish adult population such as diet fortification and/or supplementation, may be required. 


\section{Acknowledgements}

This work was supported by grants from the Instituto de Salud Carlos III-Fondo de Investigaciones Sanitarias (FIS: PI11/01092), and Red Temática de Investigación Cooperativa en Envejecimiento y Fragilidad (RETICEF) (RD06/0013/1007). "Instituto de Salud Carlos III". Ministerio de Economía y Competitividad. Spain. FEDER financing susceptible funds

\section{Conflicts of interest:}

José M. Olmos, José L. Hernández, Pilar García-Velasco, Josefina Martínez, Javier Llorca, and Jesús González-Macías declare that they have no conflict of interest. 


\section{Tables and Figures}

Table 1. Baseline characteristics of the population studied.

\begin{tabular}{|c|c|c|c|c|c|}
\hline \multicolumn{2}{|l|}{ Parameter } & Total $(n=1811)$ & Men (n=657) & Women $(n=1154)$ & $\mathbf{p}$ \\
\hline \multicolumn{2}{|l|}{ Age (yrs) } & $63.7 \pm 9.3$ & $64.6 \pm 8.4$ & $63.2 \pm 9.8$ & 0.001 \\
\hline \multicolumn{2}{|l|}{$\mathrm{BMI}\left(\mathrm{Kg} / \mathrm{m}^{2}\right)$} & $28.9 \pm 4.4$ & $28.8 \pm 3.4$ & $29.0 \pm 4.8$ & 0.49 \\
\hline \multicolumn{2}{|c|}{ Dairy calcium (mg/day) } & $634 \pm 347$ & $562 \pm 338$ & $675 \pm 345$ & $<0.0001$ \\
\hline \multicolumn{2}{|c|}{ Creatinine $(\mathrm{mg} / \mathrm{dl})$} & $0.9 \pm 0.2$ & $1.08 \pm 0.2$ & $0.9 \pm 0.2$ & $<0.0001$ \\
\hline \multicolumn{2}{|c|}{$25(\mathrm{OH}) \mathrm{D}(\mathrm{ng} / \mathrm{ml})$} & $22.6 \pm 7.9$ & $23.5 \pm 7.7$ & $22.1 \pm 7.9$ & $<0.0001$ \\
\hline \multicolumn{2}{|l|}{ PTH (pg/ml) } & $51.3[40.8-64.3]$ & $51.6[40.1-63.4]$ & $51.4[41.1-64.8]$ & 0.41 \\
\hline \multicolumn{2}{|l|}{ P1NP (ng/ml) } & $40.6[30.0-54.2]$ & $33.2[25.4-43.8]$ & $44.9[34.2-58.7]$ & $<0.0001$ \\
\hline \multicolumn{2}{|c|}{$\beta-\mathrm{CTX}(\mathrm{ng} / \mathrm{ml})$} & $0.33[0.22-0.46]$ & $0.26[0.19-0.37]$ & $0.36[0.25-0.49]$ & $<0.0001$ \\
\hline \multicolumn{2}{|c|}{$\mathrm{BMD}, \mathrm{LS}\left(\mathrm{g} / \mathrm{cm}^{2}\right)$} & $0.960 \pm 0.153$ & $1.019 \pm 0.154$ & $0.927 \pm 0.142$ & $<0.0001$ \\
\hline \multicolumn{2}{|c|}{$\mathrm{BMD}, \mathrm{FN}\left(\mathrm{g} / \mathrm{cm}^{2}\right)$} & $0.759 \pm 0.127$ & $0.815 \pm 0.123$ & $0.728 \pm 0.118$ & $<0.0001$ \\
\hline \multicolumn{2}{|c|}{$\mathrm{BMD}, \mathrm{TH}\left(\mathrm{g} / \mathrm{cm}^{2}\right)$} & $0.900 \pm 0.138$ & $0.980 \pm 0.128$ & $0.856 \pm 0.123$ & $<0.0001$ \\
\hline \multicolumn{2}{|c|}{ Education (yrs) } & $9.0 \pm 2.4$ & $9.3 \pm 2.7$ & $8.8 \pm 2.2$ & $<0.0001$ \\
\hline \multicolumn{2}{|c|}{ Current Smoker (\%) } & 14 & 18 & 12 & $<0.0001$ \\
\hline \multicolumn{2}{|c|}{ Current alcohol (\%) } & 25 & 47 & 12 & $<0.0001$ \\
\hline \multicolumn{2}{|c|}{ Season $(\% \text { winter })^{a}$} & 36 & 36 & 36 & 0.99 \\
\hline \multicolumn{2}{|c|}{ No. of chronic diseases } & $1[0-2]$ & $1[0-2]$ & $1[0-2]$ & 0.21 \\
\hline \multirow[t]{3}{*}{ Exercise (\%) } & - Sedentary & 2 & 1 & 3 & 0.01 \\
\hline & - Moderate & 41 & 31 & 47 & $<0.0001$ \\
\hline & - High & 57 & 69 & 50 & $<0.0001$ \\
\hline
\end{tabular}

\footnotetext{
${ }^{a}$ December-April
}

Distribution of PTH, P1NP, $\beta$-CTX, and number of chronic diseases was skewed, and median [interquartile range] are showed.

25(OH)D: 25-hydroxyvitamin D; PTH: intact parathyroid hormone; P1NP: Aminoterminal propeptide of type I collagen ; $\beta$-CTX: C-terminal telopeptide of type I collagen; BMD, LS: Bone mineral density at the lumbar spine; BMD, FN: Bone mineral density at the femoral neck; BMD, TH: Bone mineral density at the total hip. 
Table 2. Levels of $25(\mathrm{OH}) \mathrm{D}, \mathrm{PTH}$, and dairy calcium intake according to different age groups.

\begin{tabular}{lccc}
\hline & Group & n & Mean \pm SD \\
\hline Age (yrs.) & $<60$ & 711 & $55 \pm 3^{*}$ \\
& $60-75$ & 844 & $67 \pm 5^{*}$ \\
25(OH)D (ng/ml) & $>75$ & 256 & $80 \pm 3$ \\
& $<60$ & 711 & $23.8 \pm 7.9^{*}$ \\
PTH (pg/ml) & $60-75$ & 844 & $22.9 \pm 7.7^{*}$ \\
& $>75$ & 256 & $18.3 \pm 9.4$ \\
& $<60$ & 711 & $49.7 \pm 15.9^{*}$ \\
Dairy calcium intake (mg/day) & $60-75$ & 844 & $54.5 \pm 19.1^{*}$ \\
& $>75$ & 256 & $66.8 \pm 23.7$ \\
& $600-75$ & 711 & $644 \pm 352$ \\
& $>75$ & 256 & $626 \pm 345$ \\
& & & \\
\hline
\end{tabular}

* $\mathrm{p}<0.0001$ (comparisons with the oldest group).

25(OH)D: 25-hydroxyvitamin D; PTH: intact parathyroid hormone 
Table 3. Differences in mean serum PTH, P1NP, and $\beta$-CTX levels, BMD, and dairy calcium intake according to serum $25(\mathrm{OH}) \mathrm{D}$ quartiles.

\begin{tabular}{|c|c|c|c|c|}
\hline \multirow[b]{2}{*}{ Parameter } & \multicolumn{4}{|c|}{ Serum 25(OH)D (ng/ml) ${ }^{\mathrm{a}}$} \\
\hline & $<17(n=462)$ & $17-22(n=438)$ & $22-28(n=480)$ & $>28(n=431)$ \\
\hline $25(\mathrm{OH}) \mathrm{D}(\mathrm{ng} / \mathrm{ml})$ & $13.4(0.15)^{* * *}$ & $19.6(0.15)^{* * *}$ & $24.9(0.14)^{* * *}$ & $33.2(0.15)$ \\
\hline PTH $\quad(\mathrm{pg} / \mathrm{ml})$ & $61.2(0.9)^{* * *}$ & $55.3(0.9)^{* * *}$ & $52.6(0.8) * * *$ & $47.8(0.9)$ \\
\hline P1NP (ng/ml) & $46.2(0.9)$ & $41.6(0.9)^{* *}$ & $43.4(0.9)$ & $45.9(0.9)$ \\
\hline$\beta-\mathrm{CTX}(\mathrm{ng} / \mathrm{ml})$ & $0.38(0.09)$ & $0.33(0.09)^{*}$ & $0.35(0.09)$ & $0.37(0.09)$ \\
\hline $\mathrm{BMD}, \mathrm{LS}\left(\mathrm{g} / \mathrm{cm}^{2}\right)$ & $0.957(0.07)$ & $0.959(0.07)$ & $0.965(0.07)$ & $0.958(0.07)$ \\
\hline $\mathrm{BMD}, \mathrm{FN}\left(\mathrm{g} / \mathrm{cm}^{2}\right)$ & $0.746(0.06)^{*}$ & $0.758(0.05)$ & $0.764(0.05)$ & $0.770(0.06)$ \\
\hline $\mathrm{BMD}, \mathrm{TH}\left(\mathrm{g} / \mathrm{cm}^{2}\right)$ & $0.885(0.06)^{* *}$ & $0.894(0.06)$ & $0.913(0.05)$ & $0.913(0.06)$ \\
\hline Dairy calcium (mg/day) & $612(16.7)^{*}$ & $610(16.3)^{* *}$ & $670(15.6)$ & $685(16.9)$ \\
\hline
\end{tabular}

Values represent mean (SE). * $\mathrm{p}<0.05 * * \mathrm{p}<0.01 * * * \mathrm{p}<0.001$, as compared to the highest quartile $(>28$ $\mathrm{ng} / \mathrm{ml}$ ).

a Adjusted for age, sex, BMI, level of education, exercise, alcohol use, smoking, number of chronic diseases, serum creatinine, and season of vitamin D determination.

25(OH)D: 25-hydroxyvitamin D; PTH intact parathyroid hormone; P1NP: Aminoterminal propeptide of type I collagen ; $\beta$-CTX: C-terminal telopeptide of type I collagen; BMD, LS: Bone mineral density at the lumbar spine; BMD, FN: Bone mineral density at the femoral neck; BMD, TH: Bone mineral density at the total hip. 
Table 4. Results of stepwise multiple linear regression analysis with serum 25(OH)D levels as dependent variable (overall sample).

\begin{tabular}{lcc}
\hline & $\beta(\mathrm{SE})$ & $\mathrm{p}$ \\
\hline Age $(\mathrm{yr})$ & $-0.164(0.020)$ & $<0.0001$ \\
Sex (male) & $-0.058(0.417)$ & 0.02 \\
Dairy calcium intake (mg/day) & $0.086(0.001)$ & $<0.0001$ \\
BMI $\left(\mathrm{Kg} / \mathrm{m}^{2}\right)$ & $-0.133(0.040)$ & $<0.0001$ \\
Serum PTH (pg/ml) & $-0.228(0.527)$ & $<0.0001$ \\
Winter season & \\
Smoking & $0.184(0.417)$ & $<0.0001$ \\
Alcohol use & $-0.075(0.500)$ & 0.001 \\
No. of chronic diseases & $-0.049(0.423)$ & 0.04 \\
Serum creatinine (mg/dl) & $-0.086(0.280)$ & $<0.0001$ \\
\hline
\end{tabular}

Dependent variable: serum 25(OH)D (ng/ml)

${ }^{a}$ December-April

$\mathrm{R}^{2}$ for the regression model: 0.214 
Figure 1. Adjusted LOESS plots showing the relationship between serum 25(OH)D, and (A) PTH (p<0.001); (B) BMD at the femoral neck (p<0.01); (C) BMD at the total hip $(\mathrm{p}<0.01)$, and (D) Dairy calcium intake $(\mathrm{p}<0.01)$.

\section{$\underline{\text { Footnote (Figure 1) }}$}

Grey lines represent 95\% CI.

Figure 2. Adjusted mean serum PTH values according to serum $25(\mathrm{OH}) \mathrm{D}$ values and dairy calcium intake ${ }^{\mathrm{a}}$.

\section{$\underline{\text { Footnote (Figure 2) }}$}

a Adjusted for age, sex, BMI, level of education, exercise, alcohol use, smoking, number of chronic diseases, serum creatinine, and season of vitamin D determination.

$* \mathrm{p}<0.05 * * \mathrm{p}<0.001$, referred to the highest quartile (within the same group of calcium intake) 


\section{References}

1. Holick MF. Vitamin D deficiency. N Engl J Med 2007; 357: 266-281.

2. McKenna MJ. Differences in vitamin D status between countries in young adults and the elderly. Am J Med 1992; 93: 69-77.

3. Van der Wielen RP, Lowik MR, van der Berg H, de Groot LC, Haller J, Moreiras O, van Staveren WA. Serum vitamin D concentrations among elderly people in Europe. Lancet 1995; 346: 207-210.

4. Kuchuk NO, van Schoor NM, Pluijm SM, Chines A, Lips P. Vitamin D status, parathyroid function, bone turnover, and BMD in postmenopausal women with osteoporosis: Global perspective. J Bone Miner Res 2009; 24: 693-701.

5. Bruyère $\mathrm{O}$, Slomian J, Beaudart $\mathrm{C}$, Buckinx F, Cavalier E, Gillain S, Petermans J, Reginster JY. Prevalence of vitamin D inadequacy in European women aged over 80 years. Arch Gerontol Geriatr. 2014; 59: 78-82.

6. Spiro A, Buttriss JL. Vitamin D: An overview of vitamin D status and intake in Europe. Nutr Bull 2014; 39: 322-350.

7. Lips P. Vitamin D deficiency and secondary hyperparathyroidism in the elderly: Consequences for bone loss and fractures and therapeutic implications. Endocr Rev 2001; 22: 447-501.

8. Bates CJ, Carter GD, Mishra GD, O’Shea D, Jones J, Prentice A. In a population study, can parathyroid hormone aid the definition of adequate vitamin D status?. Osteoporos Int 2003; 14: 152-159.

9. Carter GD. 25-Hydroxyvitamin D: a difficult analyte. Clin Chem 2012; 58: 486488.

10. Heaney RP. Vitamin D requirement in health and disease. Steroid Biochem Mol Biol 2005; 97: 13-19. 
11. Steingrimsdottir L, Gunnarson O, Indidason OS, Franzson L, Sigurdson G. Relationship between serum parathyroid hormone levels, vitamin D sufficiency, and calcium intake. JAMA 2005; 294: 2336-2341.

12. Adami S, Viapiana O, Gatti D, Idolazzi L, Rossini M. Relationship between serum parathyroid hormone, vitamin D sufficiency, age, and calcium intake. Bone 2008; 42: 267-270.

13. Kuchuck NO, Pluijm SM, van Schoor NM, Looman CWN, Smit JH, Lips P. Relationships of serum 25-hydroxyvitamin D to bone mineral density and serum parathyroid hormone and markers of bone turnover in older persons. J Clin Endocrinol Metab 2009; 94: 1244-1250.

14. Hernández JL, Olmos JM, Pariente E, Martínez J, Valero C, GarcíaVelasco P, Nan D, Llorca J, González-Macías J. Metabolic syndrome and bone metabolism. Menopause 2010; 17: 955-961

15. Olmos JM, Hernández JL, Martínez J, Pariente E, Llorca J, González-Macías J. Bone turnover markers in Spanish adult men. The Camargo Cohort Study. Clin Chim Acta 2010; 411: 1511-1515.

16. Díez A, González-Macías J, Marín F, Abizanda M, Alvarez R, Gimeno A, et al., for the ECOSAP study investigators. Prediction of absolute risk of non-spinal fractures using clinical risk factors and heel quantitative ultrasound. Osteoporos Int 2007; 18: 629-639.

17. Berry EM, Gupta MM, Turner SJ, Burns RR. Variations in plasma calcium with induced changes in plasma specific gravity, total protein, and albumin. Br Med J 1973; IV: 640-643.

18. Looker AC, Orwoll ES, Johnston CC, et al. Prevalence of low femoral bone density in older U.S. adults from NHANES III. J Bone Miner Res 1997; 12: $1761-1768$. 
19. Riancho JA, Valero C, Hernández JL, Olmos JM, Paule B, Zarrabeitia A, González-Macías J. Biomechanical indices of the femoral neck estimated from the Standard DXA output: Age- and sex-related differences. J Clin Densitomet 2007; 10: 39-45.

20. Ruston D, Hoare J, Henderson L, Bates CJ, Prentice A, Birch M. National Diet and Nutrition Survey: Adults aged 19-64 years. In Volume 4: Nutritional Status (anthropometry and blood analytes), blood pressure and physical activity. TSO. London. 2004.

21. Rockell JEP, Skeaff CM, Williams SM, Green TJ. Serum 25-hydroxyvitamin D concentrations of New Zealanders aged 15 years and older. Osteoporos Int 2006, 17: $1382-1389$.

22. Looker AC, Dawson-Hughes B, Calvo MS, Gunter EW, Sahynoun NR. Serum 25-hydroxyvitamin D status of adolescents and adults in two seasonal subpolulations from NHANES III. Bone 2002; 30: 771-777.

23. Dawson-Hughes B, Mithal A, Bonjour JP, Boonen S, Burckhardt P, Fuleihan GE, et al. IOF position statement vitamin D recommendations for older adults. Osteoporos Int 2010; 21. 1151-1154.

24. Holick MF, Binkley NC, Bischoff-Ferrari HA, Gordon CM, Hanley DA, Heaney RP, Murad MH, Weaver CW, Evaluation, treatment, and prevention of vitamin D deficiency: an Endocrine Society clinical practice guideline, J Clin Endocrinol Metab 2011; 96: 1911-1930.

25. Gómez Alonso C, Naves ML, Fernández JL, Díaz-López JB, Fernández MT, Cannata J. Vitamin D status and secondary hyperparathyroidism: The importance of 25-hydroxyvitamin D cutt-off levels. Kidney Int 2003; 85: S44S48. 
26. González-Molero I, Morcillo S, Valdés S, Pérez-Valero V, Botas P, Delgado E, Hernández D, Olveira G, Rojo G, Gutiérrez-Repiso C, Rubio-Martín E, Menéndez E, Soriguer F. Vitamin D deficiency in Spain: a population-based cohort study. Eur J Clin Nutr 2011; 65: 321-8.

27. Quesada JM, Jans I, Benito P, Jimenez JA, Bouillon R. Vitamin D status of elderly people in Spain. Age Ageing 1989; 18: 392-397.

28. Pérez-Llamas F, López-Contreras MJ, Blanco MJ, López-Azorín F, Zamora S, Moreiras O. Seemingly paradoxical seasonal influences on vitamin D status in nursing-home elderly people from Mediterranean area. Nutrition 2008; 24: 414420.

29. Calatayud M, Jódar E, Sánchez R, Guadalix S, Hawkins F. Prevalence of deficient and insufficient vitamin $\mathrm{D}$ levels in a young healthy population. Endocrinol Nutr 209; 56: 164-169.

30. Gómez-de-Tejada MJ, Navarro MD, Saavedra P, Quesada JM, Jódar E, Sosa M. Prevalence of osteoporosis, vertebral fractures and hypovitaminosis D in postmenopausal women living in a rural environment. Maturitas 2014; 77:282-6.

31. Quesada-Gómez JM, Diaz-Curiel M, Sosa-Henriquez M, Malouf-Sierra J, Nogues-Solan X, Gomez-Alonso C, Rodriguez-Mañas L, Neyro-Bilbao JL, Cortes X, Delgadillo J. Low calcium intake and inadequate vitamin D status in postmenopausal osteoporotic women. J Steroid Biochem Mol Biol 2013; 136: 175-177.

32. Docio S, Riancho JA, Pérez A, Olmos JM, Amado JA, González-Macías J. Seasonal deficiency of vitamin D in children: a potential target for osteoporosispreventing strategies. J Bone Miner Res 1998; 13:544-548. 
33. Úbeda N, Basagoiti M, Alonso-Aperte E, Varela-Moreiras G. Hábitos alimentarios, estado nutricional y estilos de vida en una población de mujeres menopáusicas españolas. Nutr Hosp 2007, 22: 313-321.

34. Bernal M, Cortés G, Giner A, Orden I, Horno M, Benedicto I. ¿Ha mejorado la dotación de vitamina D3 en España?. Actuales niveles en una muestra de población. Rev Esp Geriatr Gerontol 2010; 45: 15-18.

35. Mc Donald HM, Mavroeidi A, Barr RJ, Black AJ, Fraser WD, Reid DM. Vitamin D status in postmenopausal women living at higher latitudes in the UK in relation to bone health, overweight, sunlight exposure and dietary vitamin D. Bone 2008; 42: 996-1003.

36. Webb AR, Kline L, Holick MF. Influence of season and latitude on the cutaneous synthesis of vitamin D3: Exposure to winter sunlight in Boston and Edmonton will not promote vitamin D3 synthesis in human skin. J Clin Endocrinol Metab 1988; 67: 373-378.

37. McLaughin J, Holick MF. Aging decreases the capacity of human skin to produce vitamin D3. J Clin Invest 1985; 76: 1536-1538.

38. Wacker M, Holick MF. Sunlight and Vitamin D: A global perspective for health. Dermatoendocrinol 2013; 5: 51-108.

39. Tovar-Sánchez A, Sánchez-Quiles D, Basterretxea G, Benedé JL, Chisvert A, Salvador A, Moreno-Garrido I, Blasco J. Sunscreen products as emerging pollutants to coastal waters. PLoS One 2013; 8: e65451.

40. Patel S, Hyer S, Barron J. Glomerular filtration rate is a major determinant of the relationship between 25-hydroxyvitamin D and parathyroid hormone. Calcif Tissue Int 2007; 80: 221-226. 
41. Pasco JA, Henry MJ, Nicholson GC, Brennan SL, Kotowicz MA. Behavioural and physical characteristics associated with vitamin D status in women. Bone 2009; 44: 1085-1091.

42. Nimitphong H, Sritara C, Chailurkit LO, Chanprasertyothin S, Ratanachaiwong W, Sritara P, Ongphiphadhanakul B. Relationship of vitamin D status and bone mass according to vitamin D-binding protein genotypes. Nutr J 2015;14:29.

43. Institute of Medicine (IOM). Dietary Reference Intakes for Calcium and Vitamin D. Washington, DC: National Academies Press, 2011.

44. Aloia JF, Talwar SA, Pollack S, Feuerman M, Yeh JK. Optimal vitamin D status and serum parathyroid hormone concentrations in African American women. Am J Clin Nutr 2006; 84: 602-609.

45. Vieth R, Ladak Y, Walfish PG. Age-related changes in the 25-hydroxyvitamin D versus parathyroid hormone relationship suggest a different reason why older adults require more vitamin D. J Clin Endocrinol Metab 2003; 88: 185-191. 
Click here to download Figure: Figure 1.TIF

\section{Figure 1}
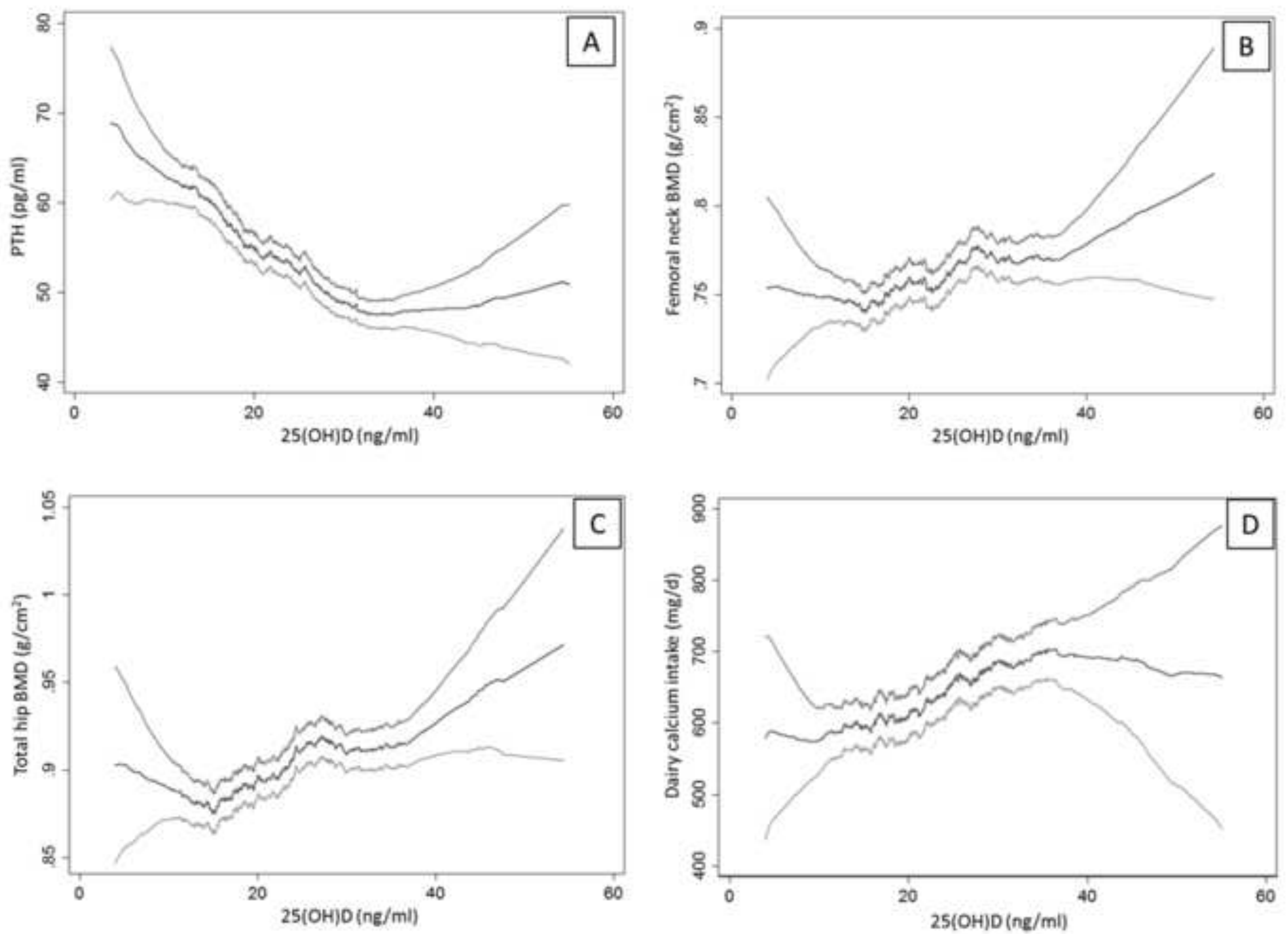
Click here to download Figure: Figure 2.TIF

Figure 2

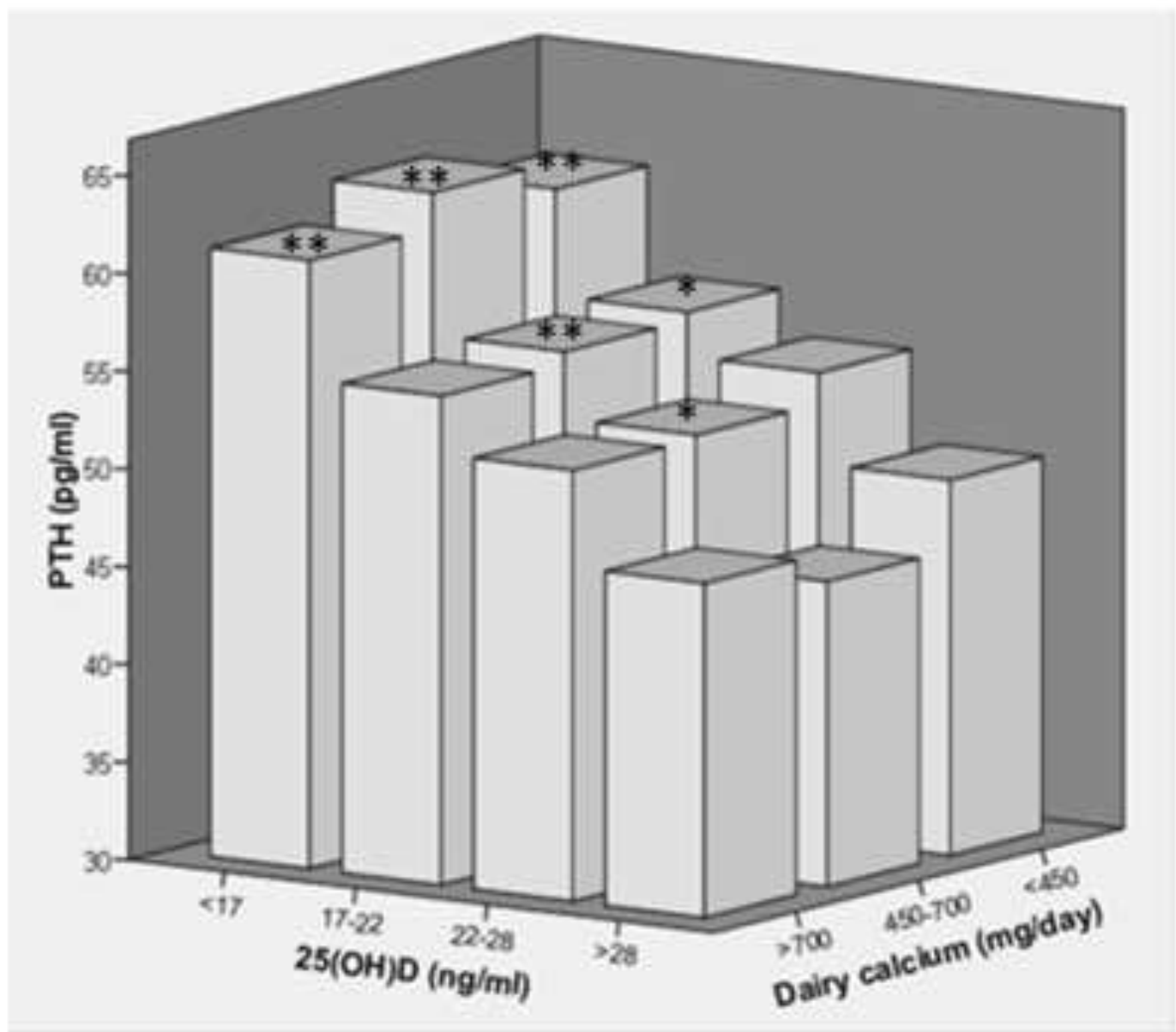

